\title{
踵骨骨折に対するプレート固定の術後成績
}

\author{
大迫 浩 文* 今林正 明* 堀川良治* 矢 崎 雄一郎* \\ 福 山勝 朗* 今林 正 典* 森 本 典 夫*
}

\section{Operative Treatment for Calcaneal Fracture with Plate}

Hirofumi Osako*, Masaaki Imabayashi*, Ryoji Horikawa*, Yuichiro Yazaki*, Katsuro Fukuyama*, Masanori Imabayashi*, and Norio Morimoto*

【目的】後距踵関節面に転位があり整復困難な踵骨骨折に対して，外側プレート固定を行い，その術後 成績を検討した。【対象】術後追跡期間が 1 年以上の 12 例 13 足で, 男性 9 例 9 足, 女性 3 例 4 足, 手術 時年齢は平均 60.1 歳であった.【方法】臨床成績評価は Maxfield の判定基準を用いた。単純レントゲン でのベーラー角, 横径指数, CT での後距踵関節面評価を術前・術後で比較した。 また職場復帰の状態・ 合併症などを調査した。【結果】臨床成績は 9 例が excellent, 2 例が very good, 1 例が poor であった. Poor の 1 例を除き全例が元の職場に復帰していた。べーラー角は術前平均 $-1.5^{\circ}$ から $20^{\circ}$ に改善し, 横 径指数は全例で改善が認められた。術後 CT での後距踵関節面の整復は概称良好であった。合併症として 5 足に創治癒遷延がみられた。【考察】外側プレート固定は早期に運動・荷重が可能であり, 後距踵関節 面に転位があり保存的に整復困難な踵骨骨折に対して有用であると考える.

We treated calcaneal fractures by means of lateral approach using a calcaneal plate, and evaluated the clinical results. The mean age at the time of surgery was 60.1 (range: 36 to 78 ). The mean duration of follow-up was 3.4 years.

Eleven feet were treated with the ACE calcaneal plate, and two feet were treated with the Rabbit plate. The clinical result evaluation according to the Maxfield criteria was as follows: excellent in nine feet; very good in two feet; poor in one foot.

Pre-and postoperative changes in radiographic findings were studied. The improvement of the Böhler angle, width index, and intra-articular displacement was reflected in the clinical result. This method is considered to be an effective treatment for intra-articular calcaneal fractures.

Key words : calcaneal fractures (踵骨骨折), open reduction and plate fixation（観血的整復・プレー 卜固定), lateral approach (外側アプローチ)

\section{は じめに}

踵骨関節内骨折は種々の治療法が報告されているが 合併症が多く治療に難渋することが多い，我々は後距 踵関節面の転位が整復困難な踵骨骨折に対して観血的 に後距踵関節面及び外側壁の解剖学的整復を行い，プ レート固定後, 早期リハビリを行っている. 今回, そ の治療成績を検討し本法の有用性, 問題点について考 察したので報告する。

\section{対象と方 法}

平成 14 年 4 月から平成 18 年 3 月までに当院で手術
を受けた踵骨骨折患者は 21 例で, その内, プレート 固定を行った踵骨骨折は男性 9 例 9 足, 女性 3 例 4 足, 計 12 例 13 足であった。手術時年齢は $36 \sim 78$ 歳（平 均 60.1 歳) で, 術後追跡期間は 1 年から 4 年で平均 3 年 4 ヶ月であった.

受傷原因は全例 1 10 m の高さより転落であった. 合併損傷として, 第 1 腰椎圧迫骨折 2 例, 足関節 外果骨折 1 例, 反対側踵骨骨折 1 例を認めた.

単純レントゲンでの骨折の分類は, Essex-Lopresti 分類 ${ }^{1}$ を用いた。 II-B が 2 足, II-C が 9 足, II-E が 2 足であった。

CT での骨折の分類は, Sanders 分類 ${ }^{7)}$ を用いた.

* 医療法人明正会今林整形外科病院 Imabayashi Hospital for Orthopaedic Surgery, Kagoshima, Japan 


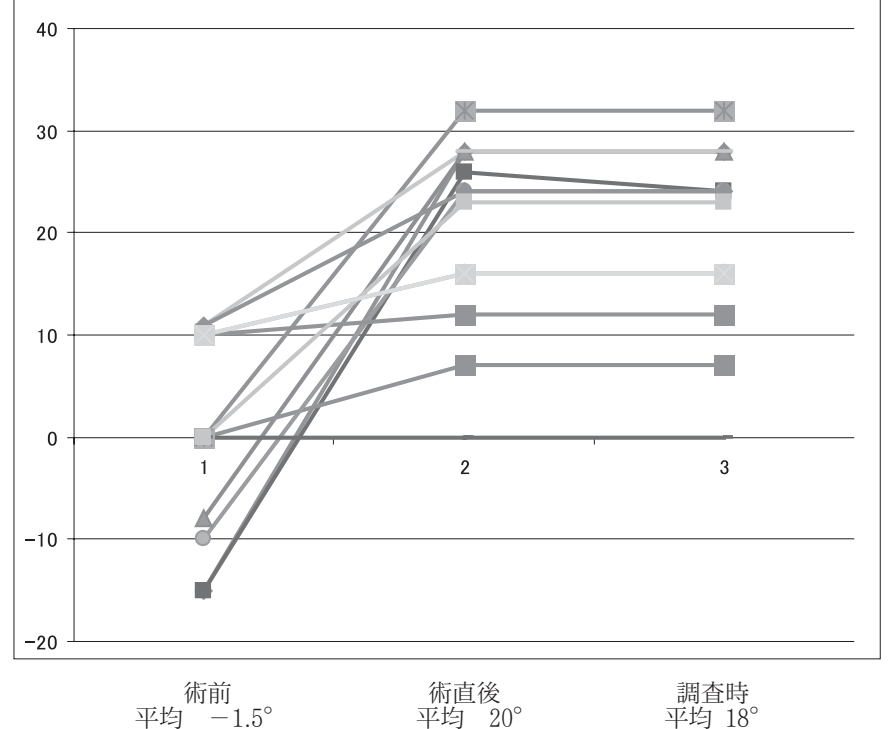

図 1 Böhler 角の推移

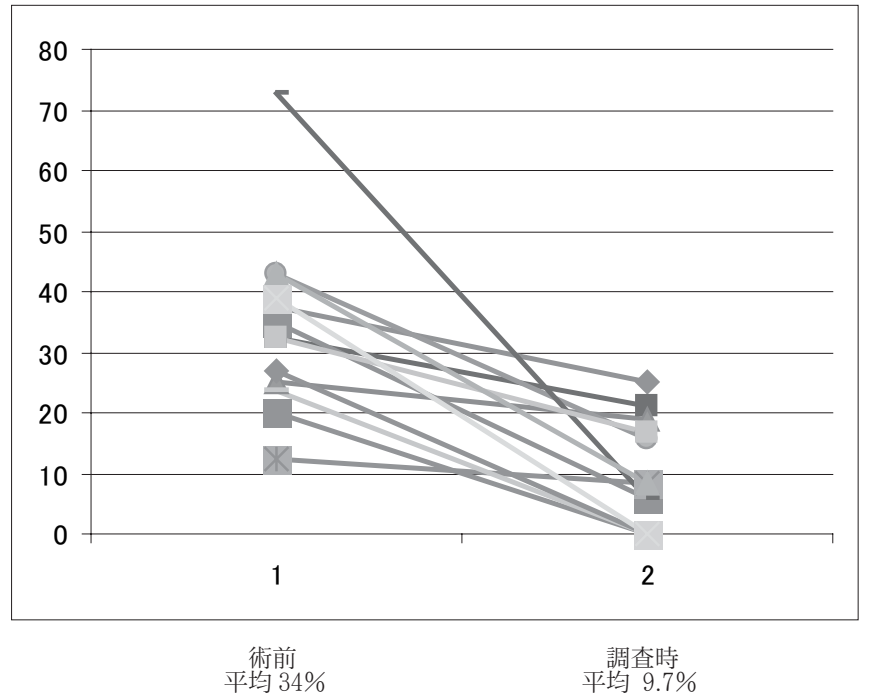

図 2 横径指数の变化

II $\mathrm{A}$ が 3 足， II B が 1 足， III $\mathrm{AB}$ が 6 足， III $\mathrm{AC}$ が 1 足，IVが 2 足であった。

手術手技は Ollier の横切開を利用し展開，腓腹神 経を同定保護した後，骨折部を展開，外側壁を反転さ せ,落ち込んだ骨片を整復し，キュルシュナー鋼線で 仮固定後，プレート固定した。骨欠損が大きく整復し
た関節面が再転位しそうな場合は人工骨を充満する （主にセラタイトを使用している）。11足に MDM 社 カルカネアルプレート，2足にベストメディカル社ラ ビットプレートを用いて，外側壁を圧迫固定した。 人 工骨の充填は 10 足に行った。術後は，PTB 装具装着 し術後早期より歩行訓練開始し 4 5 週より部分荷重 
開始した。骨癒合の状況に応じて，8～10 週で全荷重 の時期を判断した.

臨床成績は Maxfield の判定基準 ${ }^{5)}$ を用いて評価し た。画像評価では単純レントゲンでの Böhler 角, 横 径指数測定 ${ }^{8)}$, CT での関節面評価を術前・術後に行 い比較した。また職場復帰の状況・合併症の有無につ いて調査した。

結果

臨床成績は 9 例が excellent，2 例が very good， 1
例が poor であった。 poor の症例は Essex-Lopresti 分類 II-E，Sanders IV型の開放骨折例であった。

合併症として，創の遷延治癒が 5 例認められたが皮 弁や皮膚移植は必要なく治癒した。また足趾屈曲拘縮 が 2 例認められた。 2 足で術直後に腓腹神経の刺激症 状を訴えたが，経過観察時には消失していた。深部感 染は認められなかった。

excellent, very good 群の 11 例は受傷前の職業に 復帰しており, poorの 1 例は退職後, 再就職となった。

Böhler 角は術前平均 $-1.5^{\circ}$ から術後 $20^{\circ}$ に改善して
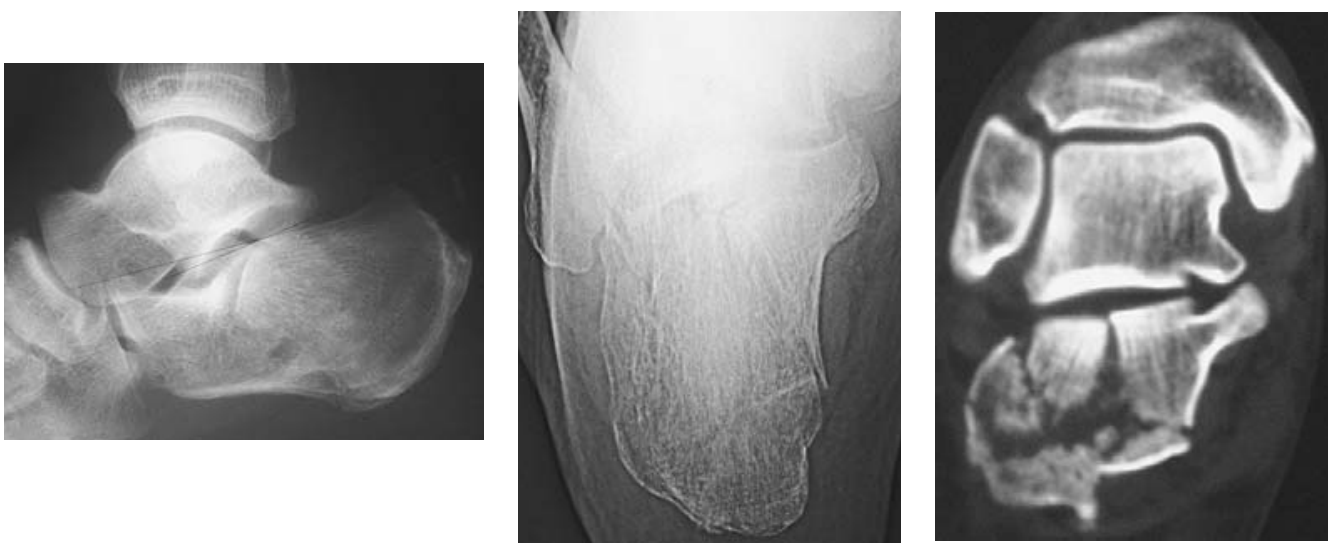

術前
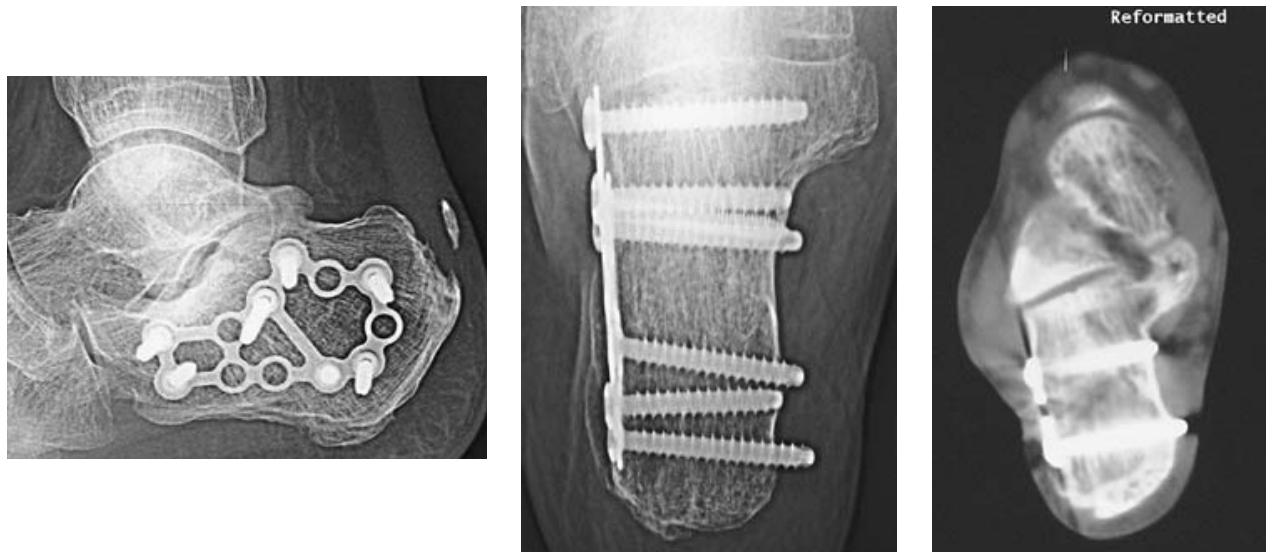

術後 3 年 4 ヶ月

図 3

症例 63 歳 男性 $\mathrm{E}-\mathrm{L}$ 分類 $\mathrm{II}-\mathrm{B}$, Sanders 分類 $\mathrm{III} \mathrm{AB}$

術後 3 年 4 ヶ月の現在, Maxfield の判定基準では Excellent であり現職に復帰 している.

Böhler 角は術前 $-10^{\circ}$ から $24^{\circ}$ に，横径指数は術前 $43 \%$ が $16 \%$ に改善している. CT で関節面の整復む良好である. 
おり, 最終経過観察時も $18^{\circ}$ と維持されていた（図 1 ). 横径指数は術前平均 34\%が術後平均 $9.7 \%$ に改善して いた（図 2 ). CT での関節面評価では 11 足について は骨折面の整復は良好であったが，Sanders 分類IVの 2 足については $2 \mathrm{~mm}$ 以上の step off がみられた。

\section{症 例 供 覧}

63 歳, 男性, 土木作業員, 作業中 $1.5 \mathrm{~m}$ の高さよ り転落し受傷。合併損傷なし。既往歴に糖尿病あり. Essex-Lopresti 分類 II -B, Sanders 分類は III AB で あった、MDMのカルカネアルプレートを使用し整 復固定を行った。術後 3 年 4 ヶ月の観察時, Maxfield の判定基準では excellent であり現職に復帰 している。術後後距踵関節の整復は良好で, Böhler 角は術前 $-10^{\circ}$ から $24^{\circ}$ に改善している。横径指数も 術前 43\%が 16\%に改善している。CT で関節面の整 復が良好であることが確認できる（図３）.

\section{考察}

近年， CT による後距踵関節面の転位の評価が容易 になったことで積極的にプレートによる観血的内固定 術が行われることが多くなってきている。また，薄く 踵骨への適合性のよいプレートの出現により良好な成 績が報告されている23(3)4)6)9)。当院では，後距踵関節 面の転位がある踵骨骨折の患者が受診した場合，可能 な限り大本法に準じて徒手整復を行い，整復が得られ ない症例については手術を選択している，麻酔下に， まず徒手及び Westhues 法にて整復し，後距踵関節面 の転位が整復困難な踵骨骨折に対しては観血的に整復 後，プレート固定を行っている．踵骨骨折治療の目標 は後距踵関節面の解剖学的整復, 横径増大や踵骨内反 変形の防止, 早期運動・荷重による骨萎縮発生の防止 などが挙げられるが，外側プレート固定は(1)後距踵関 節面の解剖学的整復が直視下に行える(2)外側壁を整復・ 固定できるので横径増大を防止できる(3)早期の運動療 法・荷重が可能などの利点があり, 後距踵関節面に転 位のある踵骨骨折に対して合理的な手技であり，今回 の調査でも骨移植を含む強固な内固定と早期のリハビ リテーションを行うことによって良好な成績を得られ ていた.

プレート固定の欠点としては, 腓腹神経損傷のリス クがあり，それを避けようとすると創治癒の遅延を起
こしやすいとの報告が多い，今回の調査でも 5 例に創 治癒の遷延が認められた。 L字皮切では創遷延治癒を 起こしにくいとされているが，近位側と遠位側でやは り神経損傷の可能性が残るため，我々は Ollier 皮切 を使用し腓腹神経を最小限剥離し保護している。遷延 治癒を避けるためには軟部組織の愛護的操作が必要で あり，また腫脹が強い時期には本法は避けるべきと考 えている。

レントゲン評価では，成績良好であった群は， Böhler 角や横径指数の改善がみられ，関節面の良好 な整復状態が得られており，横径指数の改善と関節面 の解剖学的整復が臨床成績の向上につながると考えて いる.

今回の調査で成績不良であった $\mathrm{E}-\mathrm{L}$ 分類 II - $\mathrm{E}$ 型 や Sanders 分類IV型などの高度粉砕例では，予後不 良との報告が多く今後の課題と考えられる。

\section{ま と め}

(1)後距踵関節に転位のある踵骨骨折に対するプレート 固定の治療成績を検討した。

(2)Sanders IV型の粉砕例の 1 例を除いて，良好な成 績をおさめることができた。

\section{参 考 文 献}

1) Essex-Lopresti, P. : The mechanism, reduction technique, and results in fractures of the os calcis . Br. J Surg., 39 : 395-419, 1952.

2) 古岡邦人ほか：踵骨骨折の治療. 整外之労外, 26(3)： 355-362, 1983

3）林 博志ほか：踵骨骨折に対するプレート固定法の検 討. 骨折, 27(2)：733-737, 2005.

4）伊藤孝紀ほか：クジラプレートを用いた踵骨骨折の治 療経験。骨折, 28(3) : 527-529, 2006.

5) Maxfield, J. E., McDermott, F. J. : Experiences with the Palmer open reduction of fractures of the calcaneus. J. Bone Joint Surg., 37-A : 99-106, 1955.

6) 岡田正人ほか：踵骨骨折に対する観血的整復骨移植術 の成績．日本災害医学会会誌，43(6)：410-418，1995.

7) Sanders, R., et al. : Operative treatment in 120 displaced intraarticular calcaneal fractures ; Results using a prognostic computed tomography scan classification. Clin. Orthop., 290 : 87-95, 1993.

8）杉本和也ほか：踵骨骨折の新しい治療法について。奈 良医学雑誌，30：267-292，1988.

9）田邊龍樹ほか：踵骨関節内骨折の観血的治療経験．整 外之災外，54(3)：498-502，2005. 